\title{
Simultaneous Spectrophotometric Determination of Hypertension Drug's in Commercial Pharmaceutical by Chemometric Methods
}

\author{
A. Hakan Aktas (Corresponding author) \\ Suleyman Demirel University, Science and Art Faculty \\ Department of Chemistry, Isparta, Turkey \\ E-mail: hakanaktas@sdu.edu.tr \\ Yavuz Tuna \\ Suleyman Demirel University, Graduate School of Natural and Applied Sciences \\ Department of Chemistry, Isparta, Turkey \\ E-mail: yavuztuna@yahoo.com
}

The research is financed by Suleyman Demirel University Scientific Project FYL-2019-7348.

\begin{abstract}
In this study, chemometric approaches using UV spectrophotometry method developed models for simultaneous determination of valsartan (VAL) and amlodipine (AMP) in drug samples. It was used to calculate calibration mixtures between 232 and $254 \mathrm{~nm}$ wavelengths at $2 \mathrm{~nm}$ intervals for Val and AML spectra at various concentrations. For chemometric analysis of data, the least squares calibration method and basic component regression were used, and the parameters of chemometric procedures were optimized. The analytical performances of this chemometric method were compared by characterizing the sum of residual error squares (PRESS), estimated standard error (SEP), and recoveries (\%). A number of synthetic mixtures containing different concentrations of VAL and AML were studied to control the predictive ability of Applied chemometric methods. This method was successfully applied to the actual samples, not affected by the auxiliaries as indicated in the recovery study results. The results obtained in this review encourage these chemometric methods to implement these strategies for standard research and quality control of the two active ingredients.
\end{abstract}

Keywords: Valsartan, Amplodipine, Partial Least Squares Calibration, Principal Component Regression

DOI: $10.7176 / \mathrm{JSTR} / 6-12-01$

\section{Ticari İlaçlarda Hipertansiyon İlaçlarının Kemometrik Yöntemlerle Eşzamanlı Spektrofotometrik Tayinleri}

Özet

Bu çalışmada, UV spektrofotometri yöntemi kullanılarak kemometrik yaklaşımlarla ilaç örneklerinde valsartan (VAL) ve amlodipin (AMP) eşzamanlı tayini için modeller geliştirilmiştir. Çeşitli konsantrasyonlarda VAL ve AML spektrumları için $2 \mathrm{~nm}$ aralıklarla 232 ile $254 \mathrm{~nm}$ dalga boyları arasındaki kalibrasyon karışımlarını hesaplamak için kullanıldı. Verilerin kemometrik analizi için en küçük kareler kalibrasyon yöntemi ve temel bileşen regresyonu kullanıldı ve kemometrik prosedürlerin parametreleri optimize edildi. Bu kemometrik yöntemin analitik performansları, artık hata karelerinin (PRESS), tahmini standart hatanın (SEP) ve geri kazanımların (\%) toplamını karakterize ederek karşılaştırıldı. Farklı konsantrasyonlarda VAL ve AML içeren bir dizi sentetik karışım, uygulanan kemometrik yöntemlerin tahmin kabiliyetini kontrol etmek için çalışıldı. Bu yöntem, gerçek numunelere başarıyla uygulandı, geri kazanım çalışması sonuçlarında belirtildiği gibi yardımcı 1 | $\mathrm{P}$ a g e www.iiste.org 
maddelerden etkilenmedi. Bu incelemede elde edilen sonuçlar, bu kemometrik yöntemleri, iki aktif bileşenin standart araştırma ve kalite kontrolü için bu stratejileri uygulamaya teşvik etmektedir.

Anahtar Kelimeler: Valsartan, Amplodipin, En Küçük Kareler Kalibrasyonu, Temel Bileşen Analizi

\section{Introduction}

Multivariate calibration methods have been an important application area for chemometry, as they have been applied to many different branches, and especially to analytical chemistry. Many of the applied chemometric methods involve multivariate calibration. In recent studies of chemometry, most of their development, especially in the last two decades, has been based mainly on the applications of the partial least squares (PLS) algorithm and basic component regression (PCR). PLS and PCR are generally considered to be the main regression techniques for multivariate data. As a result of applying such useful chemometric methods to combined drug analyses, fast, simple, cheap and reproducible results are obtained.

Modern spectroscopic instruments used today are so fast that they can produce hundreds of spectra in minutes for a given sample containing multiple components. On the contrary, univariate calibration methods require a system without interference and are quite slow as they are not suitable for such data. Multivariate calibration is especially preferred today in drug analysis, as it is studied in many fields, as it relates to data containing device responses measured at multiple wavelengths for a sample containing multiple components.

The popular advances in chemometrics and computers in recent years have led to the development of several variable calibration methods (Haaland et al, 1988; Wentzell et al, 1997) for the analysis of complex chemical mixtures such as drug formulations.

Amlodipine/valsartan is a blood pressure lowering combination drug. It contains amlodipine, a dihydropyridine-type calcium channel blocker, and valsartan, an angiotensin receptor blocker. This combination is usually well tolerated and effective for the reduction of blood pressure (Eckert et al, 2013).

Amlodipine is used with or without other medications to treat high blood pressure. Lowering high blood pressure helps prevent strokes, heart attacks, and kidney problems. Amlodipine belongs to a class of drugs known as calcium channel blockers. It works by relaxing blood vessels so blood can flow more easily. Amlodipine is also used to prevent certain types of chest pain (angina). It may help to increase your ability to exercise and decrease the frequency of angina attacks. It should not be used to treat attacks of chest pain when they occur.

Valsartan, sold under the trade name Diovan among others, is a medication used to treat high blood pressure, heart failure, and diabetic kidney disease (Corea et al, 1996). It is a reasonable initial treatment for high blood pressure. It is taken by mouth. Versions are available as the combination valsartan/hydrochlorothiazide, valsartan/amlodipine, valsartan/amlodipine/hydrochlorothi azide, or valsartan/sacubitril (Oparil et al, 1996). Common side effects include feeling tired, dizziness, high blood potassium, diarrhea, and joint pain. Other serious side effects may include kidney problems, low blood pressure, and angioedema. Use in pregnancy may harm the baby and use when breastfeeding is not recommended. It is an angiotensin II receptor antagonist and works by blocking the effects of angiotensin II.

In the presence of excipients in the examples, without any separation, the mixture, containing two or more compounds, determining the solubility of the systems at the same time is one of the important issues of the pharmaceutical industry and its analytical chemistry. The literature survey reveals that several methods were reported for the individual estimation of VAL and AMP. The simultaneous quantitative determination of both drugs at the same time in pharmaceutical tablets using various methods including HPLC and first derivative of the ratio spectrophotometric (Kul et al, 2010 ; Varghese, 2011), HPLC and Thin layer Chromatography (Varghese and Ravi, 2011), spectrophotometric (Chitlange et al, 2008; Mohammed 2011), HPLC-MS (Lena et al, 2007), TLC (Dhaneshwar, 2009) have been described for many mixtures. Working two forms of active ingredient are shown in Figure 1. 


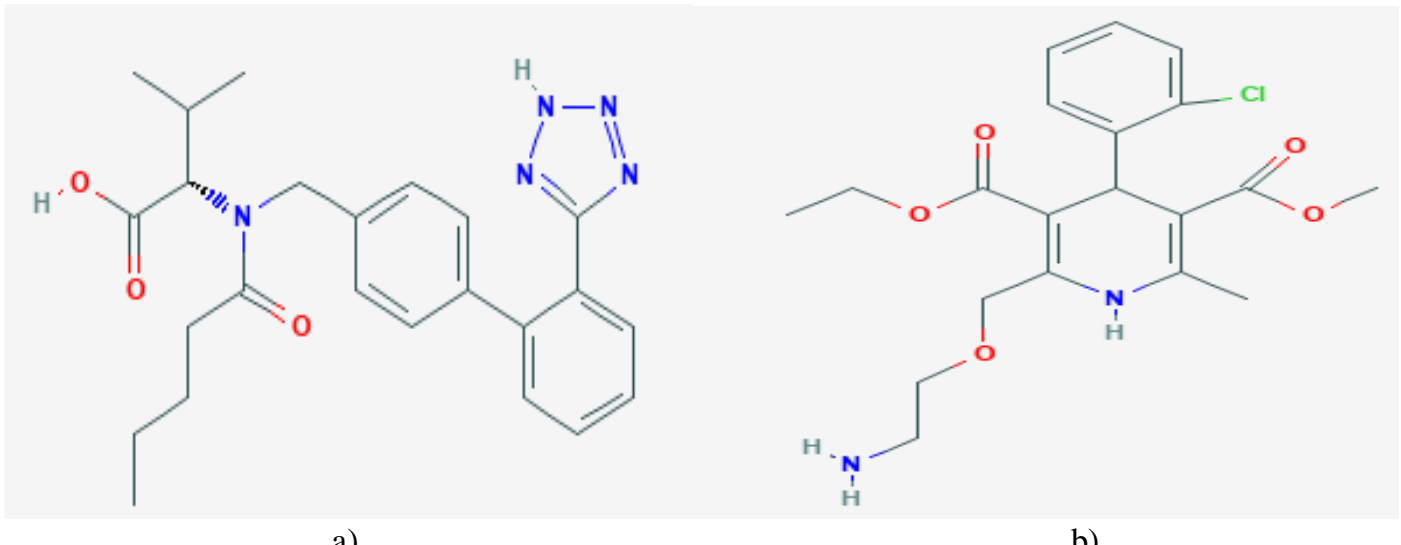

a)

b)

Figure 1. Structure of the drugs a) VAL b) AML

The multivariate calibration techniques use full spectrum, full automation, multivariate data analysis and the reduction of noise and the advantages of the selection calibration model. In addition, these multivariate calibrations do not need any separation procedure, they are very cheap, very easy to apply and very sensitive. For these reasons these multivariate techniques are popular today.

In this study, two powerful chemometric methods were applied to analyze synthetic mixtures and tablets consisting of VAL and AML in the presence of interactions of absorption spectra. The application of chemometrics is vital to the success of identifying clinical drugs at the same time as it allows interpretation of multivariate data.

\section{Experimental Section}

2.1. Apparatus

A Shimadzu (Model UV-1700) UV-Visible spectrometer (Shimadzu, Kyoto, Japan), equipped with $1 \mathrm{~cm}$ matched quartz cells was used for spectrometric measurements.

\subsection{Standard solutions}

Analytical grade materials were used in experiments. Stock solutions of $100 \mathrm{mg} / 100 \mathrm{~mL}$ VAL and AML were prepared in $0.1 \mathrm{M}$ Methanol. The solutions were stable for the least a week if they had been stored in a cool $\left(<25^{\circ} \mathrm{C}\right)$ and dark place.

2.3. Pharmaceutical preparations A commercial drug preparations; Exforge ${ }^{\circledR}$ tablet produced by Novartis Pharma, Turkey, containing $10 \mathrm{mg}$ VAL and $160 \mathrm{mg}$ AML per tablet, was analyzed by the proposed chemometric techniques.

\subsection{Procedure for dosage form}

A precisely weighed pummeled tablets comparable to $100 \mathrm{mg}$ of the considered medications was separated with $10 \mathrm{~mL}$ of methanol, and sonicated for around $30 \mathrm{~min}$. The concentrates were separated into $100 \mathrm{~mL}$ volumetric carafes at that point washed and weakened to volume with refined water. Aliquots these arrangements were moved into a progression of $10 \mathrm{~mL}$ volumetric jars and the examination were finished as spectrometric method. Every one of the systems were connected to the last arrangement.

\subsection{Chemometric methods}

The PLS and PCR chemometric methods are factor research techniques; it is a prediction attempt in which a scientific model is studied using partial foci and ghost information from a reference arrangement, followed by an adjustment attempt in which the model is used to determine. The uncertain specimen is detected in its range. These techniques are similarly called factor strategies because they convert the first factors into less symmetric factors called elements or basic components (PCs), which are flat mixtures of the first factors. At the point where multivariate tuning approaches are connected in spectrophotometric multi-segment examination, a link is created between the result and

3 | P a g e

www.iiste.org 
fixing information obtained from reference tests by referring to the factors of the framework. New factors are created by PCs. The calculation of this new lattice is regulated by the calculation open to the repetition technique adopted.

The real distinction in the current capabilities of these two strategies is that PLS predict that it is superior to PCR when there are freely different large ghost segments covering random direct baselines or imaginary highlights of the study. The ideal setting technique is based on specific test conditions. Regardless, PLS seems to have made a sensible decision about a wide variety of conditions.

\section{Results and Discussion}

In order to build the chemometric calibration, a training set was randomly prepared by using the standard mixture solution containing $1.0-3.0 \mu \mathrm{g} / \mathrm{mL}$ VAL and $0.5-2.5 \mu \mathrm{g} / \mathrm{mL}$ AML in the variable proportions as shown in Table 1. The absorbance data matrix was obtained by measuring at the 12 wavelengths with the intervals $\Delta \lambda=2 \mathrm{~nm}$ in the $232-254 \mathrm{~nm}$ spectral region. The prepared calibrations of two techniques using the absorbance data sets were used to predict concentration of the unknown values of VAL and AML in their mixture.

Table 1. Concentration set design for the preparation of PLS and PCR calibration

\begin{tabular}{|cccccc|}
\hline Mix & $\operatorname{VAL}(\mu \mathrm{g} / \mathrm{mL})$ & $\mathrm{AML}(\mu \mathrm{g} / \mathrm{mL})$ & Mix & $\mathrm{VAL}(\mu \mathrm{g} / \mathrm{mL})$ & $\mathrm{AML}(\mu \mathrm{g} / \mathrm{mL})$ \\
\hline $\mathbf{1}$ & 1.0 & 0.5 & $\mathbf{9}$ & 1.8 & 2.0 \\
\hline $\mathbf{2}$ & 1.5 & 1.0 & $\mathbf{1 0}$ & 1.8 & 2.5 \\
\hline $\mathbf{3}$ & 2.0 & 1.5 & $\mathbf{1 1}$ & 1.0 & 1.3 \\
\hline $\mathbf{4}$ & 2.5 & 2.0 & $\mathbf{1 2}$ & 1.5 & 1.3 \\
\hline $\mathbf{5}$ & 3.0 & 2.5 & $\mathbf{1 3}$ & 2.0 & 1.3 \\
\hline $\mathbf{6}$ & 1.8 & 0.5 & $\mathbf{1 4}$ & 2.5 & 1.3 \\
\hline $\mathbf{7}$ & 1.8 & 1.0 & $\mathbf{1 5}$ & 3.0 & 1.3 \\
\hline $\mathbf{8}$ & 1.8 & 1.5 & & & \\
\hline
\end{tabular}

A calibration for each technique was computed in the MINITAB 16.0 and PLS Toolbox 4.0 software by using set consisting of two drugs and their absorbance data. The multivariate calibrations of two techniques were used to predict the unknown concentrations of VAL and AML in the samples.

The application adequacy of a calibration model can be explained in several ways. Validation of the calibrations configured for the training set and synthetic binary mixtures of both drugs can be verified by statistical parameters. These results can also be examined numerically. One of the best ways to do this is by reviewing the estimated residual error frames total or PRESS. To calculate PRESS, it calculates errors between expected and predicted values for all samples, squares and is combined.

$$
\text { PRESS }=\sum_{i=1}^{n}\left(C_{i}^{\text {added }}-C_{i}^{\text {found }}\right)^{2}
$$

Strikingly speaking, this is not a correct way to normalize the PRESS values when not all of the data sets contain the same number of samples. If we want correctly compare PRESS values for data sets that contain differing numbers of samples, we should convert to standard error of prediction (SEP), which is given by following formula.

$$
\mathrm{SEP}=\sqrt{\frac{\sum_{i=1}^{n}\left(C_{i}^{\text {added }}-C_{i}^{\text {found }}\right)^{2}}{n-1}}
$$

Where $C_{i}^{\text {added }}$ the added concentration of drug is, $C_{i}^{\text {found }}$ is the found concentration of drug and $\mathrm{n}$ is the total number of the synthetic mixtures. The SEP can provide a good measure of how well, on average, the calibration model performs. Often, however, the performance of the calibration model

4 | P a g e

www.iiste.org 
varies depending on the analyte level. In the application of two chemometric techniques to the synthetic mixtures containing two drugs in variable compositions, the mean recoveries and relative standard deviations for PLS and PCR were found to be $99.9938 \%, 0.4252 ; 100.0035 \%, 0.0921$ and $100.0011 \%$, $0.0005 ; 99.9718 \%, 0.0101$ respectively for VAL and for AML (Table 2).

Table 2. Recovery values for the applied chemometric methods

\begin{tabular}{|c|c|c|c|c|c|}
\hline \multicolumn{2}{|c|}{ Mixture $(\mu \mathrm{g} / \mathrm{mL})$} & \multicolumn{2}{|c|}{ Recovery (\%) } & \multirow[b]{3}{*}{ VAL } & \multirow[b]{3}{*}{ AML } \\
\hline \multicolumn{2}{|r|}{ PLS } & \multicolumn{2}{|l|}{ PCR } & & \\
\hline VAL & AML & VAL & AML & & \\
\hline 20 & 10 & 99.8860 & 100.0640 & 100.0005 & 99.9580 \\
\hline 25 & 10 & 99.7856 & 100.1490 & 100.0004 & 99.9560 \\
\hline 30 & 10 & 99.9780 & 100.0180 & 100.0003 & 99.9520 \\
\hline 10 & 15 & 100.5740 & 99.8933 & 100.0020 & 99.9760 \\
\hline 15 & 15 & 100.5080 & 99.8586 & 100.0013 & 99.9720 \\
\hline 20 & 15 & 100.0810 & 99.9700 & 100.0010 & 99.9707 \\
\hline 10 & 20 & 99.1490 & 100.1185 & 100.0020 & 99.9805 \\
\hline 15 & 20 & 100.1907 & 99.9600 & 100.0013 & 99.9790 \\
\hline 20 & 20 & 100.0195 & 99.9945 & 100.0010 & 99.9770 \\
\hline 15 & 25 & 99.3406 & 100.1100 & 100.0013 & 99.9816 \\
\hline 20 & 25 & 100.3725 & 99.9172 & 100.0010 & 99.9804 \\
\hline \multirow[t]{3}{*}{25} & 25 & 100.0408 & 99.9888 & 100.0008 & 99.9792 \\
\hline & Mean & 99.9938 & 100.0035 & 100.0011 & 99.9718 \\
\hline & RSD* & 0.4252 & 0.0921 & 0.0005 & 0.0101 \\
\hline
\end{tabular}

\section{RSD*: Relative Standard Deviation}

According to the added concentration and the concentration found in samples, the PRESS and SEP values of PLS and PCR techniques were calculated $0.0028 ; 0.0393$ and $0.0002 ; 4.75 .10^{-7}, 0.0550 ; 0.0153$ and $0.0044 ; 0.0002$ respectively for VAL and AML (Table 3).

Table 3. Statistical parameters in the calibration-prediction for PLS and PCR methods

\begin{tabular}{|lllll|}
\hline Parameter & \multicolumn{1}{c}{ PLS } & \multicolumn{2}{c|}{ PCR } & \\
\hline & VAL & AML & VAL & AML \\
\hline PRESS & 0.0028 & 0.0393 & 0.0002 & $4.75 .10^{-7}$ \\
\hline SEP & 0.0550 & 0.0153 & 0.0044 & 0.0002 \\
\hline $\mathbf{r}$ & 0.9999 & 1.0000 & 1.0000 & 1.0000 \\
\hline Intercept & 0.9999 & 1.0000 & 1.0000 & 1.0000 \\
\hline Slope & 0.0016 & 0.0001 & 0.0002 & 0.0039 \\
\hline
\end{tabular}

Linear regression analysis of the concentration added for each drug and each calibration technique and the concentration contained in the synthetic mixtures was performed. In this regression analysis, the correlation coefficient (r), intercept, slope and relative standard deviation values for the chemometric 
techniques suggested in Table 3 were found satisfactory. As can be seen, all statistical values showed that all techniques are suitable for determining two active ingredients in synthetic mixtures.

Accuracy and precision for the analysis of VAL and AML substances in the prepared synthetic mixtures at three different concentration levels $(15.00,20.00$ and $25.00 \mu \mathrm{g} / \mathrm{mL}$ for VAL and 10.00, 15.00 and $20.00 \mu \mathrm{g} / \mathrm{mL}$ for AML) in intra-day $(n=6)$ and inter-day $(n=6)$, was tested for the applicability of the proposed chemometric methods. The calculated results for percent relative error, standard deviation and relative standard deviation were presented in table 4 and 5. Good accuracy and precision were observed for the results obtained by PLS and PCR calibrations.

Table4. Accuracy and precision results for PLS

\begin{tabular}{|c|c|c|c|c|c|c|c|c|c|c|c|}
\hline \multicolumn{12}{|c|}{ Intra- day $(n=6)$} \\
\hline \multicolumn{2}{|c|}{ Added $(\mu \mathrm{g} / \mathrm{ml})$} & \multicolumn{5}{|c|}{ VAL } & \multicolumn{5}{|c|}{ AML } \\
\hline VAL & AML & Found & SD & $\% \mathrm{BSS}$ & $\% \mathrm{RE}$ & $\begin{array}{l}\text { Recovery } \\
(\%)\end{array}$ & Found & SD & $\%$ BSS & $\% \mathrm{RE}$ & \begin{tabular}{|l}
$\begin{array}{l}\text { Recovery } \\
(\%)\end{array}$ \\
\end{tabular} \\
\hline 15.00 & 10.00 & 14.9993 & 0.1247 & 0.0012 & -0.0047 & 99.9953 & 9.9993 & 0.1841 & 0.0018 & -0.0070 & 99.9930 \\
\hline 20.00 & 15.00 & 20.0017 & 0.1087 & 0.0011 & 0.0085 & 100.0086 & 15.0017 & 0.1450 & 0.0014 & 0.0113 & 100.0115 \\
\hline \multirow[t]{6}{*}{25.00} & 20.00 & 24.9990 & 0.1400 & 0.0014 & -0.0040 & 99.9960 & 19.9990 & 0.1750 & 0.0017 & -0.0050 & 99.9950 \\
\hline & & & & & $\overline{\mathbf{x}}$ & 99.9999 & & & & $\overline{\mathbf{x}}$ & 99.9998 \\
\hline & & & & & SD & 0.0075 & & & & SD & 0.0102 \\
\hline & & & & & BSS & $7.48 .10^{-5}$ & & & & BSS & 0.0001 \\
\hline & & & & & LOD & 0.0247 & & & & LOD & 0.0335 \\
\hline & & & & & LOQ & 0.0748 & & & & LOQ & 0.1015 \\
\hline
\end{tabular}

\begin{tabular}{|c|c|c|c|c|c|c|c|c|c|c|c|}
\hline \multicolumn{12}{|c|}{ Inter-day $(\mathrm{n}=6)$} \\
\hline \multicolumn{2}{|c|}{ Added $(\mu \mathrm{g} / \mathrm{ml})$} & \multicolumn{5}{|c|}{ VAL } & \multicolumn{5}{|c|}{ AML } \\
\hline VAL & AML & Found & SD & $\%$ BSS & $\% \mathrm{RE}$ & \begin{tabular}{|l}
$\begin{array}{l}\text { Recovery } \\
(\%)\end{array}$ \\
\end{tabular} & Found & SD & $\%$ BSS & $\%$ RE & \begin{tabular}{|l}
$\begin{array}{l}\text { Recovery } \\
(\%)\end{array}$ \\
\end{tabular} \\
\hline 15.00 & 10.00 & 15.0045 & 0.2577 & 0.0025 & 0.0300 & 100.0097 & 10.0015 & 0.3865 & 0.0039 & 0.0150 & 100.0145 \\
\hline 20.00 & 15.00 & 19.9978 & 0.2119 & 0.0021 & -0.0110 & 99.9892 & 14.9978 & 0.2826 & 0.0028 & -0.0147 & 99.9860 \\
\hline 25.00 & 20.00 & 25.0006 & 0.1825 & 0.0018 & 0.0024 & 100.0027 & 20.0007 & 0.2282 & 0.0023 & 0.0035 & 100.0034 \\
\hline & & & & & $\overline{\mathbf{x}}$ & 100.0005 & & & & $\overline{\mathbf{x}}$ & 100.0012 \\
\hline & & & & & SD & 0.0104 & & & & SD & 0.0146 \\
\hline & & & & & $\%$ BSS & 0.0001 & & & & $\%$ BSS & 0.0002 \\
\hline & & & & & LOD & 0.0344 & & & & LOD & 0.0481 \\
\hline & & & & & LOQ & 0.1042 & & & & LOQ & 0.1458 \\
\hline
\end{tabular}


Table5. Accuracy and precision results for PCR

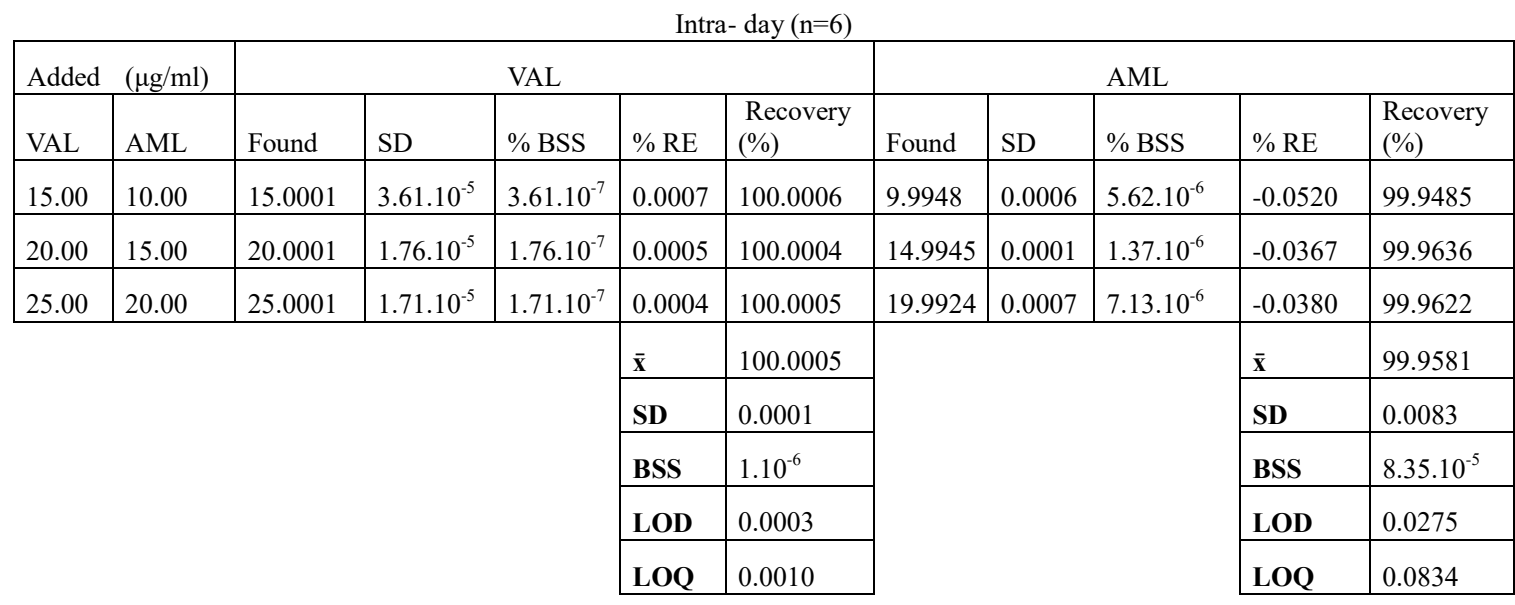

\begin{tabular}{|c|c|c|c|c|c|c|c|c|c|c|c|}
\hline \multicolumn{12}{|c|}{ Inter-day $(\mathrm{n}=6)$} \\
\hline Added & $(\mu \mathrm{g} / \mathrm{ml})$ & \multicolumn{5}{|c|}{ VAL } & \multicolumn{5}{|c|}{ AML } \\
\hline VAL & AML & Found & SD & $\%$ BSS & $\%$ RE & \begin{tabular}{|l}
$\begin{array}{l}\text { Recovery } \\
(\%)\end{array}$ \\
\end{tabular} & Found & SD & $\%$ BSS & $\% \mathrm{RE}$ & \begin{tabular}{|l} 
Recovery \\
$(\%)$
\end{tabular} \\
\hline 15.00 & 10.00 & 14.9999 & $1.03 .10^{-5}$ & $1.03 .10^{-7}$ & -0.0007 & 99.9994 & 9.9998 & $2.16 .10^{-6}$ & $2.16 .10^{-8}$ & -0.0020 & 99.9986 \\
\hline 20.00 & 15.00 & 19.9999 & $1.14 .10^{-5}$ & $1.14 .10^{-7}$ & -0.0005 & 99.9996 & 14.9998 & $1.30 .10^{-5}$ & $1.30 .10^{-7}$ & -0.0013 & 99.9991 \\
\hline 25.00 & 20.00 & 24.9999 & $9.67 .10^{-5}$ & $9.67 .10^{-8}$ & -0.0004 & 99.9998 & 19.9998 & $1.53 .10^{-5}$ & $1.53 .10^{-7}$ & -0.0010 & 99.9993 \\
\hline & & & & & $\overline{\mathbf{x}}$ & 99.9998 & & & & $\overline{\mathbf{x}}$ & 99.9990 \\
\hline & & & & & SD & 0.0002 & & & & SD & 0.0004 \\
\hline & & & & & $\%$ BSS & $2.10^{-6}$ & & & & $\%$ BSS & $3.61 .10^{-6}$ \\
\hline & & & & & LOD & 0.0007 & & & & LOD & 0.0012 \\
\hline & & & & & LOQ & 0.0020 & & & & LOQ & 0.0036 \\
\hline
\end{tabular}

A summary of the assay results for the pharmaceutical formulation is given Table6. The results of all methods were very to each other as well as to the label value of commercial drug formulation.

Table 6. Assay results for the pharmaceutical formulation (mg/tablet)

\begin{tabular}{|lll|}
\hline Drug & PLS & PCR \\
\hline VAL & $159.84 \pm 0.12$ & $160.02 \pm 0.02$ \\
Mean \pm SD* & \\
AML & $9.96 \pm 0.03$ & $9.99 \pm 0.04$ \\
Mean \pm SD* & & \\
\hline
\end{tabular}

Results obtained are average of six experiments for each technique. *SD : Standard deviation

\section{Conclusion}

PLS and PCR, powerful chemometric methods in spectrophotometric examination, have been proposed for simultaneous determination of VAL and AML in binary mixtures. Applied chemometric method strategies were successfully implemented in a commercial drug tablet. Exceptionally, the goals of covering drug mixtures have been achieved using PLS and PCR methods. As can be seen from the 
results obtained, PLS and PCR chemometric methods have been shown to give accurate and reliable results in this drug mixture.

\section{Acknowledgement}

This research work has been supported by research grants from Süleyman Demirel University Scientific Research Project FYL-2019-7348.

\section{References}

Eckert S, Freytag SB, Müller A, Klebs SH (September 2013). "Meta-analysis of three observational studies of amlodipine/valsartan in hypertensive patients with additional risk factors". Blood Pressure. 22 (sup1): 11-21.

Corea L, Cardoni O, Fogari F et al., (1996). Valsartan, a new angiotensin II antagonist for the treatment of essential hypertension: a comparative study of the efficacy and safety against amlodipine. Clin Pharmacol Ther. 60:341-346.

Oparil S, Dyke S, Harris F et al., (1996). The efficacy and safety of valsartan compared with placebo in the treatment of patients with essential hypertension. Clin Ther. 18:797-810.

Lena K, Elisabeth L, Mimi SO, Mette K, Elsa L, Asbj Qrg SC., (2007). Simultaneous determination of 6 beta- blockers, 3 calcium- channel antagonists, 4 angiotensin- II antagonists and 1 antiarrhytmic drug in post- mortem whole blood by automated solid phase extraction and liquid chromatography mass spectrometry. Method development and robustness testing by experimental design. J Chromatogr B. 850:147-60.

Kul D, Topal BD, Kutucu T, Uslu B and Ozkan SA, (2010). High-Performance Liquid Chromatographic and First Derivative of the Ratio Spectrophotometric Determination of Amlodipine and Valsartan in Their Binary Mixtures, Journal of AOAC International, 93, 3; 882890.

Chitlange, S.S., Bagri, K., Wankhede, S.., \& Sakarkar, D.M. (2008), Validated spectrophotometric estimation of valsartan and amlodipine in combined dosage form J. Pharm. Res. 7, 53-55

Dhaneshwar, S.R., Patre, N.G., \& Mahadik, M.V. (2009) Validated TLC method for simultaneous quantitation of amlodipine besylate and valsartan in bulk drug and formulation, Chromatographia 69, 157-161

Mohammed NG., (2011). Simultaneous Determination of Amlodipine and Valsartan, Analytical Chemistry Insight, 6: 53-59.

Vignaduzzo SE, Castellano PM and Kaufman TS, (2011). Development and validation of an HPLC method for the simultaneous determination of amlodipine, hydrochlorothiazide, and valsartan in tablets of their novel triple combination and binary pharmaceutical associations. J. Liq. Chromatogr. Relat. Technol., 34(19): 2383-2395.

Varghese SJ and Ravi TK, (2011). Quantitative simultaneous determination of amlodipine, valsartan and hydrochlorothiazide in "Exforge HCT" tablets using high performance liquid chromatography and high-performance thin layer chromatography. J. Liq. Chromatogr. Relat. Technol., 34(12): 981-994.

Haaland, D.M., Thomas, E.V., (1988). Partial least squares methods for spectral analysis. 1. Relation to other quantitative calibration methods and the extraction of qualitative information. Anal. Chem., 60:1193-1202.

Wentzel, P.D., Andrews, D.T., Kowalski, B.R. (1997). Maximum likelihood multivariate calibration. Anal. Chem., 69:2299-2311.

8| P a g e

www.iiste.org 